\title{
Reseña de Lope de Vega, La privanza del hombre. El nombre de Jesús, edición crítica de Victoriano Roncero López e Ignacio D. Arellano-Torres, Kassel, Reichenberger, 2018, 214 pp. ISBN: 978-3-944244-76-1
}

\section{Rocío Arana Caballero}

Universidad Internacional de la Rioja

ESPAÑA

rocio.arana@unir.net

[Hipogrifo, (issn: 2328-1308), 7.2, 2019, pp. 915-917]

Recibido: 10-09-2019 / Aceptado: 08-11-2019

DOI: http://dx.doi.org/10.13035/H.2019.07.02.64

Abarca el presente volumen 214 de las ediciones críticas de la editorial Reichenberger la recopilación de dos autos sacramentales más de Lope de Vega, editados dentro de uno de los proyectos de investigación del prestigioso GRISO. Se trata de la inacabada obra La privanza del hombre, con introducción y notas de Victoriano Roncero, y un auto de corte lírico llamado El nombre de Jesús, al cuidado de Ignacio D. Arellano-Torres.

Ambos autos tratan una temática similar, muy del gusto de Lope: lejos de disquisiciones teológicas sobre la transubstanciación, el dramaturgo ahonda en el gran amor que Dios tiene al hombre, por medio de símbolos, imágenes y alegorías. De hecho, en El nombre de Jesús aparece la Humanidad representada en el personaje de la Esposa, como bien desarrolla Arellano-Torres (pp. 112-114).

También coinciden en el protagonismo del Demonio como personaje antagonista, caracterizado como envidioso en La privanza (p. 17) y como escéptico, pero con un escepticismo que también encubre envidia, en El nombre de Jesús (p. 117). La causa de tales celos es en ambas ocasiones la misma: esa predilección de Dios por el ser humano, en demérito de las criaturas angélicas.

Aquí terminan las similitudes y empiezan las diferencias: en cuanto al auto mismo, las obras publicadas en esta edición resultan desiguales en cuanto a la forma: La privanza es un ejemplar interesante pero inacabado, inconcluso, y resulta meritorio el esfuerzo por sacar a la luz una obra que merece su estudio pero que carece de final: «alguien rasgó la última hoja del manuscrito», afırma en la página 27 Ron- 
cero, que para el manejo textual ha cotejado el manuscrito 17017 de la Biblioteca Nacional de España y una edición de Menéndez Pelayo de la que detalla algunos errores de transcripción.

También existen claras diferencias argumentales, pues si en La privanza del hombre se adivina, desde el título, un sustrato político más allá del asunto religioso (p. 23), El nombre de Jesús es en cambio «poesía villanesca de inspiración lírica integrada en la estructura (aparente) de un auto sacramental» (p. 108).

Respecto al análisis preliminar y al tratamiento que cada experto hace de su auto, se observa cierta disparidad en estructura y epígrafes: mientras que Victoriano Roncero se centra en pormenorizar argumentos y temas, Arellano-Torres lo hace en estudiar detalladamente los personajes, aunque el objetivo es el mismo, llegar a ahondar en la temática del auto.

Coinciden sin embargo en el cuidado textual y la detallada y valiosa anotación, sello propio del grupo de investigación GRISO. Se guían ambos por el testimonio más fiable, el más cercano al mismo Lope (que en el primer caso es manuscrito y en el segundo, edición de Fiestas del Santísimo Sacramento), aun apuntando variantes y valiéndose de la ayuda que pueden aportar ediciones posteriores para su particular estudio. Así, en lo referente a las indagaciones sobre la datación de las obras, Roncero acude a distintos autores y Arellano-Torres a Menéndez Pelayo, pero ambos basan su argumentación aduciendo razones de coherencia interna áurea.

Resulta interesante reseñar, por último, algunas cuestiones en las que se detiene cada uno: La privanza del hombre es una obra de sustrato político, en el que se representa a Dios como el Rey de un estado, y virtudes y vicios forman parte de su corte. Según la dicotomía asunto/argumento instaurada por Calderón, Roncero (p. 16) establece que, si bien el asunto en este auto es religioso y eucarístico como corresponde a su género literario, el argumento es político y además aborda un tema de candente actualidad en la época: el de los peligros que puede encerrar un mal privado.

Del mismo modo identifica a Lisonja con el «bufón de corte» ( $p$ 12), siendo así que hasta los autos sacramentales deben tener su Gracioso según la comedia nueva: en El nombre de Jesús, ese papel lo hará el pastor Rústico (p. 117).

Este segundo auto posee dos asuntos principales: el valor redentor de la sangre de Cristo (p. 112), y la unión hipostática representada por un argumento de corte pastoril: las bodas entre Dios y una serrana, glosadas y comentadas por tres pastores protagonistas.

Aun advirtiendo de que los autos de Lope son muy poco alegóricos (El nombre es más bien una égloga a lo divino), Arellano-Torres desliza un apunte interesante: al comentar un pasaje del auto en el que aparece el Niño Jesús cargando con la cruz, y ante las quejas del resto de personajes que le afean ese recrearse en algo tan doloroso, insiste en ensayar los pasos de su pasión, llega a afirmar lo siguiente: 
«No deja de ser curioso el hecho de que, en una obra teatral, el propio Jesús aparezca ensayando como si de un actor se tratase, y la propia cruz descrita como escenario» (p. 121)

Dios actor y Dios rey, en resumen, Dios enamorado: tres imágenes con las que se ve a Lope de Vega muy cómodo, tres metáforas que nos desgranan con minuciosidad ambos estudios introductorios. 